\title{
Oil Price Shocks and Stock Market Performance: A comparison between Oil Exporting and Oil Importing Nations
}

\author{
Muhammad Farhan * $\quad$ Zeeshan Atiq ${ }^{\dagger} \quad$ Syed Shahid Zaheer Zaidi ${ }^{\ddagger}$
}

\begin{abstract}
The paper explores the impact of shocks in oil prices on the stock market for the oil importing and exporting nations. As Pakistan is heavily dependent on imports of oil therefore, we focus on Pakistan as an oil importing nation and have taken Iran, as an oil exporting nation because, it is considered to be among top ten nations of the world that exports oil. Various studies in Pakistan have investigates the relationship between shocks in prices of oil and return on the stock but none of the study has examined the association between shocks in oil prices and return on the stock market by comparing Pakistan and Iran as an oil importer and exporter nations of the world. This study has employed Autoregressive Distributed Lag model to find out the relationship between dependent and independent variables. We have taken prices of oil as an independent variable, whereas, stock price has been taken as a dependent variable. On the other hand, rate of exchange and rate of interest are the other independent variables. The results of this study and bound test reveals a long run association between prices of oil and the stock return for both nations. It has been indicated in the results that high oil prices have an adverse impact on market of stock for an oil importing nation (i.e., Pakistan) and have positively impacted on Iran which is an oil exporter nation. The results confirm that oil price shock contributed towards positively affecting the market of stock of an oil exporter nation but negatively affected the stock market if an oil importing nation. The author recommended the investors of both nations to evaluate various alternatives to diversify portfolios of their stock market by utilizing other financial assets.
\end{abstract}

Keywords: Oil Price shocks, Stock Market Performance, Oil Exporting Nations, Oil Importing Nations.

\section{Introduction}

In this paper, the origin of shocks in oil price has been considered by using the Auto Regressive Distributed Lag model in order to investigate the correlation between prices of oil and stock market prices for oil-exporting and oil-importing countries. The study focuses on Iran as an oil exporting nation and Pakistan as an oil importing nation. Unilabiate regime-switching EGARCH model was applied by Aloui and Jammazi (2009) to examine the relationship between crude oil shocks on Japanese, UK and French stock markets.

\footnotetext{
*Department of Public Administration, University of Karachi, Pakistan.

$\dagger$ Department of Economics, University of Karachi, Pakistan.

$\ddagger$ Department of Public Administration, University of Karachi, Pakistan.

This paper is a part of Muhammad Farhan's Ph.D. Dissertation
} 
Two episodes of series behavior were detected by them, one relative to high variance and low mean regime and the other to low variance and high mean regime, and evidence was provided that common recessions coincide with high variance and low mean regime. Furthermore, a unilabiate regime-switching GARCH model has been applied by Lee and Chiou (2011) to examine this relationship. They concluded that, when there are significant fluctuations in prices of oil, so negative impacts on S\&P 500 returns has been found due to the resultant unexpected asymmetric changes in price, but the result does not hold in a regime of lower fluctuations in oil price. Multivariate CCC-GARCH model has been applied by Cifarelli and Paladino (2010) and provided evidence that exchange rate and stock price changes are negatively related with oil price shifts. Finally, a symmetric DCCGARCH model was applied by Choi and Hammoudeh (2010) and indicated decreasing correlations with the S\&P500 index but increasing correlations among silver, Brent oil, gold, WTI oil and copper. The volatility spillovers and conditional correlations between Dow jones, FTSE100, NYSE and S\&P500 stock indices and crude oil (Brent markets and WTI) has been investigated by using symmetric DCC-GARCH model.

\section{Impact of Oil Price Shock in Oil Importing Country}

\section{Pakistan}

Pakistan is a developing country and serious macro-economic problems like staggering exchange rate, wide spread poverty, slow economic growth and unemployment are being faced by Pakistan. Resources of energy are the driving factor for the economy. Pakistan is highly dependent on oil importing and other sources of energy. According to Pakistan bureau of Statistics (PBS) released trade figures, in the year 2019-2020, $\$ 1.935$ billion on importing oil had been spent by Pakistan in comparison with $\$ 2.642$ billion of the previous year. Therefore, for the economy changing in oil prices internationally is considered as an important issue. Cost of production would be increase due to high prices of oil and consequently the profits of corporations will reduce. It also reduces demand of customers as, rise in oil prices leads to inflation, resultantly for spending less disposable amount would be available to customers. Additionally, shocks in oil prices create investment uncertainty, leading to higher rate of returns demanded by investors, so the level of investment at the stock market becomes an independent factor. The level of investment in real and financial assets are constrained by increased uncertainty, high production costs and reduced profits decreasing demand. Share prices will decrease as a result of increased discount rates and further reduction in profit. Therefore, an important role for macroeconomic fluctuations in the short to medium term has been played by changes in oil prices. Pakistan as an oil importer in nature is being examined through implication of shocks in prices of oil for market of stock. Mixed and Inconclusive results were produced by existing studies in Pakistan as former study argued negative, while positive effects of shocks in prices of oil is preferred in the rest of the paper. Methodology based on SVAR technique shows lack consensus in recent studies, as some reported shocks in oil prices from the demand side are important like Kilian and Park (2009) while the importance of supply side shocks like Gupta and Modise (2013) are advocated by others. Second, Pakistan's economy is highly dependent on importing of oil for its energy and other needs as compared with 
other developing countries. Third, Pakistan's oil consumption is increasing with much higher speed as its import of oil and for the consumption of oil, Pakistan ranks 33rd in the world for about $0.6 \%$ of the total consumption of world $97,103,871$ barrels per day has been accounted. Economy of Pakistan and its markets are highly sensitive to the movements in prices of oil price due to heavy reliance on importing of oil. Therefore, the implications of shocks in prices of oil on the markets of stock are very essential to study. Despite Pakistan's dependency on imported oil is quite high and sensitivity of its economy to price of oil changes is also very sharp still, the association between shocks in prices of oil and index of stock price are examined by only few studies. The oil price volatility and changes in stock market of china and Pakistan have been investigated. Monthly data from 1998 to 2013 has been used by them and asymmetric results are found. Prices of oil on these markets of stock has been found negatively related with each other. Asymmetric and positive impact of volatility in prices of oil on stock market index are shown by Naurin and Qayyum (2016). Shocks in prices of oil have an adverse effect and were reported by a study of Jebran, Chen, Saeed, and Zeb (2017) in periods before the financial crisis of 2007where as positive effects yields in periods after such crisis. Examining the impact of shocks in prices of oil on stock return in Pakistan as an oil importing nation is focused by this study.

\section{Impact of Oil Price Shock on Oil Exporting Nation}

\section{Iran}

Serious challenges could be created for market participants due to fluctuations in economic conditions, total revenues or international sanctions, all these have been indicated through previous investigations and studies. Over the past two decades, various fluctuations have been encountered by the oil revenues in Iran. On the other hand, the stock market fluctuations and, consequently, the volatility in the market of stock return have been indicated by the studies on the stock markets of Iran are significant. The connection between volatility of return on stock in the market of stock and fluctuations in oil revenues is the main question that could be discovered. The negative relationship between oil prices and movements in market are described through several theoretical views. From the microeconomic point of view, the companies profit have been adversely affected due to high oil prices. If the additional cost of production has not been fully transferred to consumers by the companies so the dividends and profit of company per share would be decreased (Al-Fayoumi, 2009). However, recent studies review indicates the effect of fluctuations in prices of oil believed by many researchers shows that the market are indirectly impacted which occurs through indicators of macroeconomic. Therefore, the income would be increased in those counties which are oil exporter in nature and the high oil prices fluctuations would be effected positively (Bjørnland, 2009). The shocks in prices of oil could be impacted differently on oil-exporting countries and countries which are oil importer in nature. Although inflation rate and industry cost increases due to higher prices of oil, as well as in oil importing countries expenditure reduction on goods other than oil (Barsky \& Kilian, 2004), because elasticity of crude oil prices are low (Bjørnland, 2009). Iran is an exporter of oil and Pakistan as an importer of oil and hence. the relationship would be investigated. 
The further study is as follow. The literature on shocks in prices of oil on prices of stock market is reviewed in section 2. In this study methodology, data and econometric issues are discussed in section 3. Impact on the prices of stock market due to different shocks in prices of oil are discussed in section 4 while section 5 shows recommendations and conclusion.

\section{Review of Literature}

Several review of studies would be focused in this section to examine the association between shocks in oil prices and markets of stock in both oil importing and exporting countries from both theoretical and empirical perspectives.

\section{Theoretical Background}

The mechanism of how returns on stock market are affected by oil price changes is associated by different theories. One rationale is based on the notion that the expected discounted cash flows of future will determine the fair value of a price of stock and different macroeconomic factors effect these cash flows. One of the most important factor is considered as changes in prices of oil; therefore, the expected discounted cash flows could be altered due to such changes and the price of these asset would reflect such changes. Accordingly, the cost of production would be increased due to increase in prices of oil will lead to reduction in the firm's profit, and to a greater extent share value will also reduce. Hence, markets of stock are greatly affected by oil price changes (Jones \& Kaul, 1996). Another commonly held view is that upstream oil companies get benefit by high oil prices, therefore the returns of stock in oil exporter nations companies are expected to being positively impacted by high oil prices while other oil importer nations companies have been adversely affected and high oil prices may affect negatively their cash flows, since oil is the main production cost and main source for energy.

\section{Empirical Studies}

In this section some past studies about Iran and other countries has been reviewed by this research study. Co-movements of oil price and stock market has done in many studies. We can divide these studies in two different categories, studies for oil importing and oil exporting countries. For example, Chen, Roll, and Ross (1986) explained the trend of stock prices and negative association is indicated by Jones and Kaul (1996). Hosseini Nasab, Khezri, and Rasouli (2011) employed (MS-AR) approach and wavelet analysis. The results showed that returns on stock have been positively affected by shocks in prices of oil.

Impact of income of oil exports on dividend of Tehran stock exchange and price index (TEDPIX) has been investigated by Monjazeb and Gohari (2013). They used different variables such as real investment of private sector, income of oil export, price of gold at worldwide, GDP of Iran and dummy variable. The effect of shocks in oil on stock exchange of Tehran has been examined. For investigation of relationship among variables they employed Wavelet analysis, and it has more accurate results in comparison with other 
tests. Movements in prices of oil and return on the stock market in Gulf Cooperation Council (GCC) countries have been examined by Mohanty, Nandha, Turkistani, and Alaitani (2011). Their findings showed that shocks in prices of oil has been positively and significantly exposure by stock markets at country level, except for Kuwait. Vector autoregression model to study the relation of changes in prices of oil and return on the stock in the U.S has been estimated by Sadorsky (1999). Basher, Haug, and Sadorsky (2012) found shocks in prices of Oil have significant impact on return on prices of stock in emerging markets. Park and Ratti (2008) examined significant impact of returns on stock due to shocks in prices of oil. The effects of shocks in oil prices on prices of stock vary among countries which has been shown in their results.

Shocks in prices of oil exert a strong influence on markets of stock in several countries have been confirmed by the subsequent empirical studies. For instance, prices of oil impacts negatively on equities has been argued by Huang, Masulis, and Stoll (1996); Sadorsky (1999); Papapetrou (2001). Evidence that prices of oil diversely affects returns of stock has been provided by following studies. Recently, the relationship between prices of oil and returns on stock in those countries which are dependent on oil was evaluated by Jammazi and Nguyen (2015). Depending on the country coverage, markets of stock react differently to shocks in oil is being suggested. However, a distinction between economies of importing and exporting of oil are not made by most of these studies. The nexus between the prices of oil and returns on stock for thirteen European countries has been analyzed by Park and Ratti (2008) and deduced that shocks in prices of oil exert a positive influence on exporters of oil (e.g. Norway), whereas for importers of oil vice versa has followed. Nevertheless, for a sample importers and exporters of oil, market of stock does not sensitive to shocks in prices of oil has been revealed by Apergis and Miller (2009). The oil markets is being driven by the multiplicity of hidden features. Obviously, oil price shocks responded by equity returns distinctly depending on either the market of stock is bearish or bullish. Therefore, the focus is on the returns of stock and oil price shocks and stock returns rather than on the mean effect. Settled decisions made by the market participants (having the opportunity) should be ensured through correlation asymmetries. In fact, policymakers, investors and traders attentively follow evolution of financial market despite of having dissimilar interest. Variations in stock markets to optimize the profile of risk-return has been monitored by traders.

Information on expectations of economic growth and inflation are gathered through equity prices has been employed by the regulators. Despite the rapid increase in number of studies on the relationship between markets of the stock and prices of oil, for the oil producers case. These studies used either analysis of cross-sectional data across countries or conducted data on time series on one country (Huang et al., 1996). Oil producers and oil importers are being distinguished by the global effects of prices of oil shocks on markets of stock, however, study of Wang, Wu, and Yang (2013) is exceptional but other studies have remained relatively understudied. Our study lied the originality in it. The US and other oil-importing developed countries has been mostly focused by the literature and less on countries rich in oil exporting, new markets and developing countries. The literature for oil exporting countries, between shocks in oil and market of stock is relatively sparse. Economies that are emerging included few oil exporter countries as a part of economies that 
are emerging. Oil-exporting countries has been directly considered by only few papers. For example, the relationship between prices of oil and values of equity in the oil and gas sector of Canada has been explored by Sadorsky (2000). He found a positive relationship between the index of oil equity and the crude oil prices, when oil prices increase by $1 \%$ so index value would increase by $0.305 \%$. Changes in prices of Oil of GCC countries are associated with high returns on prices of stock, except for Kuwait has been found by Mohanty et al. (2011). Between oil-importing countries and dynamic correlation of countries which are net oil exporter in nature is not differed has been found, when the investigation of dynamic correlation between stock prices and prices of oil has in process. Similar evidence has been found by Guesmi and Fattoum (2014). Some evidence has also found that prices of oil have impacted asymmetrically on returns of the stock. In particular, for oil exporting countries, increase in oil price have a positive impact on stock markets. Also, stock markets of Gulf Arab shows higher prices of oil lead to higher return on stock has been found by Demirer, Jategaonkar, and Khalifa (2015).

\section{Research Methodology}

There are very limited research studies that have examined the linkage between returns on stock and shocks in oil prices by utilizing ARDL model especially when examining this association between oil exporting and importing nations. A causal association between oil prices and return on stock has been examined by earlier research in which mostly the conventional Granger causality test was used (Granger, 1980). To investigate the non-linearity modelling approach in various nations, various research studies have been attempted. However, as far as our observation, neither ARDL model has been applied nor all financial and non-financial sectors of Pakistan and Iran have been utilized in previous research studies for the purpose of investigating the association between stock returns and shocks in prices of oil. Trading period of 60 months covering from January 2007 to December 2019 has been selected by this research paper. The author has utilized a sector level data for both Pakistan and Iran. By using internet searching and desk studies data has been collected for this research. Pakistan Stock Exchange, Bloomberg and State Bank of Pakistan are the main sources from where data of selected variables has been collected for Pakistan. Data for stock prices has been taken from Pakistan Stock Exchange, data for interest rate, exchange rate and oil prices have been taken from State Bank of Pakistan and Bloomberg respectively. While website of Central Bank www.cbi.ir is used for the extraction of exchange rate, interest rate and oil prices data for Iran. Furthermore, the data for stock prices of Iran has been taken from ceicdata.com.

In this research paper, we have used prices of crude oil, rate of exchange, return on stock and rate of interest as different variables. Time period of year 2007 to 2019 has been used in this study in order to make it unique because in case of Iran and Pakistan, recent years have not been covered in previous studies.

The shocks in oil prices impacted on stock return has been investigated for this research 
study by showing the following Augmented Dickey Fuller co integration equation.

$$
\ln (S R)=\alpha_{1}+\beta_{1} \ln (O P)+\theta_{1} \ln (E R)+\lambda_{1} \ln (I R)+\mu
$$

In above equation (i.e Eq 1) log of monthly stock return is represented by ' $L n$ SR', $\log$ of prices of oil taken as Brent Crude Oil WTI in US dollar is shown by 'Ln OP', log of exchange rate or US\$ exchange rate in terms of IRR for Iran and PKR for Pakistan are indicated by 'Ln ER', log of interest rate is represented by 'Ln IR'. The regression analysis of the exchange rates and interest rates that has been transformed to logarithm is a better match to the given data in number of respects (Gardner, Mulvey, \& Shaw, 1995). First, the log transformation puts the given data in such a form that has linear correspondence to the selected explanatory variables. Second, the log transformation of the rate variables contributed towards reducing the outliers' problem with an extreme residual for the regression analysis of the transformed rates. The log transformation let the coefficients of regression to reflect proportional differences in the dependent variable's mean and providing one-unit difference on the selected explanatory variable. For exchange rate and interest rate, proportional differences appear more reasonable as compare to the constant differences.

Asymmetric impact of oil prices on stock return in case of Pakistan is explored and considered as a main objective of this paper. Hence, the function of nonlinear form could be derived as;

$$
\ln S P_{t}=f\left(\operatorname{LnER}, \operatorname{LnOP} P_{t}, \operatorname{LnOP}, \operatorname{LnIR}\right)
$$

and the general form of asymmetric ARDL model is represented as;

$$
\ln \left(S R_{t}\right)=\alpha_{1}+\beta_{1} \ln \left(O P_{t}^{+}\right)+\theta_{1} \ln \left(O P_{t}^{-}\right)+\eta_{1} \ln \left(E R_{t}\right)+\lambda_{1} \ln \left(I R_{t}\right)+\mu_{t}
$$

Where $\log$ of stock prices are represented by Ln SR, the positive partial sum of prices of Oil are indicated by $\mathrm{LOP}+$, where, the negative partial sum of prices of oil are referred by LOPt-. While, all these are the long run coefficients to be estimated in this model and error term represents by ' $u$ '. The nonlinear ARDL model (Shin, Yu, \& GreenwoodNimmo, 2014) has been utilized for different reasons such as modelling of co integration that is existed among the oil prices, rate of exchange and performance of stock rate are permitted by it. Secondly, the selected independent variables are producing short and long run effects on the selected dependent variable has been determined by the help of ARDL nonlinear approach. The long run coefficients are provided by the above equation while the following bound test approach of Pesaran, Shin, and Smith (2001) represents the coefficients in short run of the variables.

$$
\begin{gathered}
\Delta S R t=\alpha_{1}+\sum_{k-1}^{m 1} \beta_{1} \Delta \ln \left(S P_{1-k}\right)+\sum_{k-1}^{m 2} \beta_{2} \Delta \ln \left(O P_{1-k}\right)+\sum_{k-1}^{m 3} \beta_{3} \Delta \ln \left(E R_{1-k}\right)+ \\
\sum_{k-1}^{m 4} \beta_{4} \Delta \ln \left(I R_{1-k}\right)+\lambda_{1} \ln S P_{t-1}+\lambda_{2} \ln O P_{t-1}+\lambda_{3} \ln E R_{t-1}+\lambda_{4} \ln I R_{t-1}+\epsilon_{t}
\end{gathered}
$$


Short and long run effects under the mechanism of error correction model are being provided by the above equation. Therefore, the long and short run co-integration of the shocks in prices of oil and performance of stock market are investigated as a main aim of this dissertation. Utilizing approach of error correction model and ARDL model by taking monthly data of time period 2007 to 2019 .

\section{Data Analysis}

In this study, ARDL model has been used by us for the purpose of observing link between return on stock and prices of crude oil. The purpose of facilitating the empirical studies research of an exposure of share prices to the prices of crude oil changed and also nation's industrial sector that may be affected due to the fluctuations (Jorion, 1990; El-Sharif, Brown, Burton, Nixon, \& Russell, 2005; Sadorsky, 2000). Review of various research studies have also been utilized in this research paper and a key association between return of stock and shocks in prices of oil has been reported by utilizing Autoregressive Distributed Lag model and including data for Pakistan and Iran of recent years which has not been previously reported. The impact of prices of oil and other independent variables including rate of interest, and rate of exchange on the stock return have been investigated by this study from the period of 2007 to 2018 in case of Iran and Pakistan.

\section{Unit Root Test}

In this research paper, to make all the variables stationary at first difference, we have used Augmented Dickey Fuller model and Phillip's Pearson model to observe the performance of stock market by the change in crude oil prices in Pakistan and Iran, we have applied ARDL model. Table 1 and 2 have reported the results. the unit root test results shows non-stationarity of variables at levels or at $\mathrm{I}(0)$, and the first difference have been taken by the author. While, after taking first difference of the variables, the null hypothesis declares non stationarity of series so we rejected and an alternative hypothesis is accepted by us.

Therefore, the stationary features of all the selected variables are tested through ADF test has been utilized and lag 1 has been chosen. Additionally, in order to make the series stationary we have applied the ADF and PP tests and also make sure the series should be stationary so then ARDL model would be applied efficiently for the purpose of investigating the association between stock return and prices of crude oil. unit root test results are represented in Table 1(a) (b) and Table 2 (a) (b). The results indicate that non-stationary characteristics of these variables are displayed at levels in Pakistan and Iran. after taking first differences all these series which are non-stationary in nature would become stationary. On the other hand, it is observed that second difference or I (2) characteristic of the series of each variable could not be found. 
Table 1a

Augmented Dickey Fuller Test(PAKISTAN)

\begin{tabular}{lcccc}
\hline Variables & \multicolumn{2}{c}{ ADF (at levels) } & ADF (first difference) \\
\hline & With constant & With constant and trend & With constant & With constant and trend \\
\hline LSR & t-stats & t-stats & t-stats & t-stats \\
LSP & -0.63 & -1.247 & -46.788 & -46.788 \\
LMR & -0.673 & -0.797 & -28.954 & -28.953 \\
LOP & -1.372 & -1.391 & -46.284 & -46.282 \\
LIR & -1.732 & -0.732 & -45.778 & -45.778 \\
LER & -2.003 & -1.003 & -42.037 & -42.037 \\
\hline
\end{tabular}

Source: Author's estimation

Table 1b

Phillip Perron Test(PAKISTAN)

\begin{tabular}{cccc}
\hline \multicolumn{2}{c}{ PP (at levels) } & \multicolumn{2}{c}{ PP(first Difference) } \\
\hline With constant & $\begin{array}{c}\text { With constant } \\
\text { and trend }\end{array}$ & With constant & $\begin{array}{c}\text { With constant } \\
\text { and trend }\end{array}$ \\
\hline t-stats & t-stats & t-stats & t-stats \\
\hline-1.205 & -1.67 & -13.498 & -14.676 \\
-1.699 & -0.299 & -2.249 & -2.247 \\
-1.156 & -1.155 & -2.491 & -2.402 \\
-1.534 & -1.534 & -2.511 & -2.503 \\
-0.14 & 0.231 & -25.305 & -25.303 \\
-1.668 & -1.687 & -49.578 & -49.577 \\
\hline
\end{tabular}

Source: Author's estimation

Table $2 \mathrm{a}$

Augmented Dickey Fuller Test(IRAN)

\begin{tabular}{ccccc}
\hline Variables & \multicolumn{2}{c}{ ADF (at levels) } & \multicolumn{2}{c}{ ADF (first difference) } \\
\hline & With constant & $\begin{array}{c}\text { With constant } \\
\text { and trend }\end{array}$ & With constant & $\begin{array}{c}\text { With constant } \\
\text { and trend }\end{array}$ \\
\hline LSR & -4.312 & t-stats & t-stats & t-stats \\
LSP & -2.986 & -3.817 & -32.112 & -23.112 \\
LMR & -5.113 & -1.242 & -12.753 & -45.616 \\
LOP & -5.712 & -1.613 & -22.121 & -32.617 \\
LIR & -2.224 & -5.982 & -33.766 & -44.003 \\
LER & -4.756 & -2.134 & -45.612 & -22.321 \\
\hline
\end{tabular}

Source: Author's estimation

Table 2b

Phillip Perron Test(IRAN)

\begin{tabular}{cccc}
\hline \multicolumn{2}{c}{ PP (at levels) } & \multicolumn{2}{c}{ PP(first Difference) } \\
\hline With constant & $\begin{array}{c}\text { With constant } \\
\text { and trend }\end{array}$ & With constant & $\begin{array}{c}\text { With constant } \\
\text { and trend }\end{array}$ \\
\hline t-stats & t-stats & t-stats & t-stats \\
\hline-11.323 & -14.212 & -13.498 & -22.112 \\
-8.727 & -6.322 & -2.249 & -16.133 \\
-21.331 & -17.656 & -2.491 & -32.372 \\
-9.223 & -21.323 & -2.511 & -8.413 \\
15.62 & 13.512 & -25.305 & -25.717 \\
-1.668 & -1.687 & -49.578 & -24.776 \\
\hline
\end{tabular}

Source: Author's estimation 


\section{Bound Test}

Bound testing or ARDL has been used to find the association and co-integration between performance of stock market and prices of crude oil, introduced by Pesaran et al. (2001). If the upper bound is lower than the F statistics and lower bound is higher than the value of t-statistics, so the null hypothesis of bound test would be rejected. In our case, upper bound is lower than f-statistics at $1 \% 2.5 \% 5 \%$ and $10 \%$ level of significance and therefore, a significant short and long run association between independent and dependent variables have been shown by the bound test results in case of Pakistan and Iran both.

Table 3a

Autoregressive Distributed Lag model(PAKISTAN)

\begin{tabular}{|c|c|c|c|}
\hline \multicolumn{4}{|c|}{ Long Run Determinants of Oil Prices } \\
\hline Variables & Coeff. & t-stats & Prob. \\
\hline SR & -5.449495 & -3.982283 & 0.0001 \\
\hline SR $(-1)$ & 3.178054 & 2.321339 & 0.0203 \\
\hline SR $(-2)$ & 0.929507 & 6.188854 & 0.0000 \\
\hline SP & -0.00058 & -1.95044 & 0.0511 \\
\hline $\mathrm{SP}(-1)$ & 0.000293 & 0.715765 & 0.4741 \\
\hline SP $(-2)$ & 0.000937 & 2.440075 & 0.0147 \\
\hline IR & $3.28 \mathrm{E}+02$ & 3.873629 & 0.0001 \\
\hline IR $(-1)$ & $-2.20 \mathrm{E}+03$ & -19.25554 & 0.0000 \\
\hline IR $(-2)$ & $-2.26 \mathrm{E}+03$ & -20.23048 & 0.0000 \\
\hline $\mathrm{ER}$ & $-5.43 \mathrm{E}+00$ & -3.944722 & 0.0001 \\
\hline ER $(-1)$ & $3.50 \mathrm{E}+00$ & 2.542314 & 0.0110 \\
\hline $\mathrm{OP}$ & 1.317334 & 281.2648 & 0.0000 \\
\hline $\mathrm{OP}(-1)$ & -2.259674 & -33.61916 & 0.0000 \\
\hline $\mathrm{OP}(-2)$ & -0.185669 & -23.37864 & 0.0000 \\
\hline
\end{tabular}

Source: Author's estimation

Short-Run Coefficients

\begin{tabular}{cccc}
\hline Variables & Coeff. & t-stats & Prob. \\
\hline $\mathrm{SR}(-1)$ & -2.2215 & -1.74382 & 0.0044 \\
$\mathrm{SR}(-2)$ & 2.76931 & 2.95143 & 0.05632 \\
$\mathrm{SP}(-1)$ & -5.1132 & -2.43561 & 0.01432 \\
$\mathrm{SP}(-2)$ & -2.9376 & -3.84597 & 0.00004 \\
$\mathrm{IR}(-1)$ & -8.0036 & -2.49856 & 0.08464 \\
$\mathrm{IR}(-2)$ & -6.3184 & -1.9546 & 0.16463 \\
$\mathrm{ER}(-1)$ & -3.9482 & -3.35423 & 0.00644 \\
$\mathrm{ER}(-2)$ & -7.84 & -3.20535 & 0.01123 \\
$\mathrm{OP}(-1)$ & 7.9783 & 7.43323 & 0.00436 \\
$\mathrm{OP}(-2)$ & 9.0038 & 2.49232 & 0.17568 \\
\hline Notes: All variables in logarithms; Significance \\
levels: = 5\% and 10\%
\end{tabular}

\begin{tabular}{lc} 
Diagnostics Tests & \\
\hline Adj. $R^{2}$ & 0.943481 \\
F-stats & 51.24157 \\
F-stats (Prob.) & 0.00000 \\
Durbin Watson Stat & 2.01542 \\
\hline
\end{tabular}


Table $3 \mathrm{~b}$

Autoregressive Distributed Lag model (PAKISTAN)

\begin{tabular}{lcc}
\hline \multicolumn{3}{l}{ Results of ARDL Bound Testing for co-integration } \\
\hline Variables & F statistics & Co- integration \\
\hline Op/ SR,IR,ER & 11.8715 & \\
Critical values & lower bound & upper bound \\
$1 \%$ & 2.26 & 3.35 \\
$2.50 \%$ & 2.62 & 3.79 \\
$5 \%$ & 2.96 & 4.18 \\
$10 \%$ & 3.41 & 4.68 \\
\hline
\end{tabular}

Table $4 \mathrm{a}$

Autoregressive Distributed Lag model (IRAN)

\begin{tabular}{lccc}
\hline \multicolumn{4}{l}{ Long Run Determinants of Oil Prices } \\
\hline Variables & Coeff. & t-stats & Prob. \\
\hline SR & 2.94265 & 12.22356 & 0.000 \\
SR (-1) & -4.5123 & -8.331932 & 0.001 \\
SR (-2) & -1.9245 & -18.61845 & 0.000 \\
SP & 0.001723 & 15.4490 & 0.000 \\
SP (-1) & -0.000324 & -31.1575 & 0.001 \\
SP (-2) & -0.000725 & -24.07450 & 0.011 \\
IR & $9.43 \mathrm{E}+02$ & 3.873629 & 0.001 \\
IR (-1) & $-2.24 \mathrm{E}+02$ & -23.21732 & 0.000 \\
IR (-2) & $-6.55 \mathrm{E}+03$ & -86.54231 & 0.001 \\
ER & $1.22 \mathrm{E}+00$ & 32.94612 & 0.003 \\
ER (-1) & $-7.62 \mathrm{E}+00$ & -45.25414 & 0.011 \\
OP & -1.317334 & -21.26438 & 0.000 \\
OP (-1) & 3.579264 & 61.03126 & 0.001 \\
OP (-2) & 1.561689 & 44.37864 & 0.000 \\
\hline
\end{tabular}

Autoregressive Distributed Lag model (IRAN)

\begin{tabular}{cccc}
\hline Variables & Coeff. & t-stats & Prob. \\
\hline SR $(-1)$ & -0.21377 & -3.012674 & 0.00301 \\
SR(-2) & 2.11723 & 2.811249 & 0.02124 \\
SP(-1) & -2.71724 & -3.001321 & 0.10015 \\
SP(-2) & -4.81292 & -3.117131 & 0.01293 \\
IR(-1) & -2.11501 & -2.316471 & 0.00051 \\
IR(-2) & -3.71729 & -2.213431 & 0.00321 \\
ER(-1) & -6.12712 & -3.664132 & 0.00313 \\
ER(-2) & -8.03321 & -4.723197 & 0.12943 \\
OP(-1) & 12.3198 & 7.342891 & 0.00187 \\
OP(-2) & 9.00383 & 6.653902 & 0.00782 \\
\hline
\end{tabular}

Autoregressive Distributed Lag model (IRAN)

\begin{tabular}{lc}
\hline Adj. $R^{2}$ & 0.98431 \\
F-stats & 62.34127 \\
F-stats (Prob.) & 0.000000 \\
Durbin-Watson Stats & 2.000912 \\
\hline
\end{tabular}




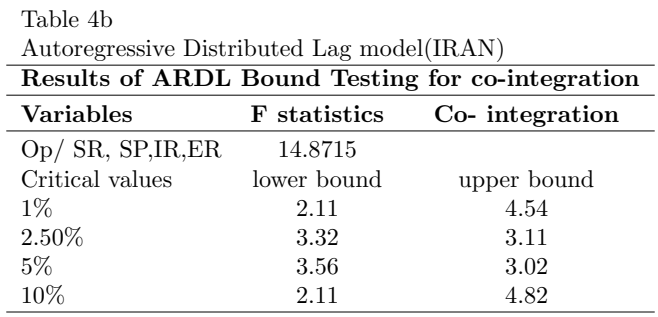

\section{ARDL}

Pesaran and Shin (1999) were the first who introduced and proposed autoregressive distributed lag model or ARDL model and Pesaran et al. (2001) made further extension in the model. The dynamic association of long and short run between the independent and dependent variables has been captured by employing this method. We have utilized the ARDL model of association among rate of interest, indices of stock return, rate of exchange and movements of prices in oil. Firstly, Akaike Information Criterion (AIC) has been used for optimal lag selection.

We have conducted ARDL bound test approach between dependent and independent variables to investigate the co integration, $\mathrm{F}$ statistics is greater than the values of Upper bound of Pesaran et al. (2001) for Pakistan at 1\% significance level. the bound test results are represented in table 4. Furthermore, upper bound values are greater than values of T-statistics at 1\% significance level. Thus a long-run co-integration relationship among stock returns in excess, return on oil prices and other explanatory variables has been found so the null hypothesis has been rejected and it shows co integration. Table 5 and 6 represent estimated long run and short run estimated results estimated by EVIEWS software. All the equations of regression are selected under AIC. Significant and positive long-run and short run effect of prices of oil on returns of stock market is found, means long run relationship has been existed between the coefficients of these variables in the following country. After a shock, the error correction term ECT(-1) which represents the adjustment speed is statistically significant at $1 \%$ significance level and are all negative which means, long run stable relationship among variables has been existed.

Other previous research studies hold our consistent results, such as stock returns in 26 countries were influenced due to the changes in prices of oil is explored. In 15 countries the coefficients are significant have been found by the result and Austria and South Africa shows remarkable outcome. coefficient is positive and significant in these countries which means despite of being oil importing in nature, stock market and oil prices are positive. Moreover, results of bound test has shown a long-run and co-integration relationship in all countries among excess return on stocks, return on oil prices and other explanatory variables. Next, the stock market returns have been adversely affected due to the shocks in oil prices found by Al-hajj, Al-Mulali, and Solarin (2018) in most cases in this study for Malaysia regardless whether shocks in oil price are in depreciation or in an appreciation direction. In addition, there is asymmetric link has been shown by the findings among shocks in prices of oil, industrial production, rate of exchange, inflation, rate of interest and return on stock market in most cases. the permanent and immediate effects of fluctuation 
in oil prices are investigated by Yahyazadehfar, Shams, and Garshasebi (2012). The stock returns are not affected significantly due to the impact of shocks in oil, and return on stocks are negatively and significantly affected by the exchange rate.

The impact of shocks in revenue of oil on the Tehran's return on stock market volatility is examined, by applying Generalized Auto Regressive Conditional Heteroscedasticity (GARCH) model. First the stock returns volatility via GARCH model was calculated then ARDL model to estimate the oil shocks effects were employed by us. the volatility of stock market are positively affected by the shocks of oil, shown by the results of this study. In the case of Iran, growth of stock price index is mainly motivated by the shocks. Moreover, the stock market return was experienced with same effects due to exchange rate and liquidity through rise in volatility, but these effects might be differ in different sectors.

Specifically, seemingly unrelated regression (SUR) method and bootstrap panel cointegration technique were employed by Arouri and Rault (2012) and evidence was provided that the performance of stock market of GCC countries has been positively impacted by the positive shocks in oil prices. Basher et al. (2012) also documents similar results. According to Aloui and Jammazi (2009) in general, the volatility of oil prices has negatively impacted market of stock behavior. Ramos and Veiga (2013) examined the asymmetric effects in prices of oil in stock markets and found that high prices of oil depress market of stock but reduction in price of oil does not necessarily increase returns of stock markets. In this area of concern an interesting finding was provided by Hammoudeh, Dibooglu, and Aleisa (2004). The volatility of the stock market of the GCC countries has been increased due to prices of oil are the major events suggested by them.

\section{Conclusion}

This research study investigates the impact of shocks in oil prices on stock return in oil exporting and oil importing nation. As Pakistan is heavily dependent on import of oil, therefore, the study focuses on Pakistan as an importer of oil and Iran has been considered as an exporter of oil. There have been very limited studies that examined the association between shocks in prices of oil and stock market by comparing both nations and by utilizing ARDL model as GARCH has been used in most of the studies in the past. This study is the first attempt to find out the relationship of shocks in prices of oil and stock return by taking recent time period of years 2008 to 2019 and utilizing ARDL model. The study has also utilized ADF and PP test to check the variables stationarity and the result of unit root test indicate the stationarity of all variables at first difference. The dependent variable includes prices of stock whereas independent variables include market return, rate of exchange, interest rate and prices of crude oil. An analysis of ARDL long run test indicate a long run association between prices of crude oil and prices of stock and shows that real effective rate of exchange, oil prices and interest rate have adversely impacted on the market of stock in Pakistan as well as shocks in prices of oil adversely affects market of stock of nation such as Pakistan. whereas, in case of Iran, effects of increased prices of oil are positively associated with market of stock and rate of exchange and rate of interest are also related positively with the volatility of stock market in Iran. results confirm that oil 
price shock contributed towards positively affecting the market of stock of an oil exporting nation and negatively affected the market of stock of an oil importing nation.

In the end, the results of this research paper recommended that policy makers and government of oil importing and exporting oil nations should improve nation's economic condition as well as capital markets by completing the mechanisms of domestic oil prices, Similarly, policy makers and government of such nations has to bring the uncertainty of global economic policy into consideration which will ensure the efficient development of domestic market of oil. On the other hand, investors should also evaluate various alternatives to diversify portfolios of their stock market by utilizing other financial assets. 


\section{References}

Al-Fayoumi, N. A. (2009). Oil prices and stock market returns in oil importing countries: The case of Turkey, Tunisia and Jordan. European Journal of Economics, Finance and Administrative Sciences, 16(1), 84-98.

Al-hajj, E., Al-Mulali, U., \& Solarin, S. A. (2018). Oil price shocks and stock returns nexus for Malaysia: Fresh evidence from nonlinear ARDL test. Energy Reports, 4 , $624-637$.

Aloui, C., \& Jammazi, R. (2009). The effects of crude oil shocks on stock market shifts behaviour: A regime switching approach. Energy Economics, 31(5), 789-799.

Apergis, N., \& Miller, S. M. (2009). Do structural oil-market shocks affect stock prices? Energy Economics, 31(4), 569-575.

Arouri, M. E. H., \& Rault, C. (2012). Oil prices and stock markets in GCC countries: Empirical evidence from panel analysis. International Journal of Finance $\mathcal{E}$ Economics, $17(3), 242-253$.

Barsky, R. B., \& Kilian, L. (2004). Oil and the macroeconomy since the 1970s. Journal of Economic Perspectives, 18(4), 115-134.

Basher, S. A., Haug, A. A., \& Sadorsky, P. (2012). Oil prices, exchange rates and emerging stock markets. Energy Economics, 34(1), 227-240.

Bjørnland, H. C. (2009). Oil price shocks and stock market booms in an oil exporting country. Scottish Journal of Political Economy, 56(2), 232-254.

Chen, N.-F., Roll, R., \& Ross, S. A. (1986). Economic forces and the stock market. Journal of Business, 21(9), 383-403.

Choi, K., \& Hammoudeh, S. (2010). Volatility behavior of oil, industrial commodity and stock markets in a regime-switching environment. Energy Policy, 38(8), 4388-4399.

Cifarelli, G., \& Paladino, G. (2010). Oil price dynamics and speculation: A multivariate financial approach. Energy Economics, 32(2), 363-372.

Demirer, R., Jategaonkar, S. P., \& Khalifa, A. A. (2015). Oil price risk exposure and the cross-section of stock returns: The case of net exporting countries. Energy Economics, $49,132-140$.

El-Sharif, I., Brown, D., Burton, B., Nixon, B., \& Russell, A. (2005). Evidence on the nature and extent of the relationship between oil prices and equity values in the UK. Energy Economics, 27(6), 819-830.

Gardner, W., Mulvey, E. P., \& Shaw, E. C. (1995). Regression analyses of counts and rates: Poisson, overdispersed poisson, and negative binomial models. Psychological Bulletin, $118(3), 392-405$.

Granger, C. W. (1980). Testing for causality: A personal viewpoint. Journal of Economic Dynamics and control, 2, 329-352.

Guesmi, K., \& Fattoum, S. (2014). The relationship between oil price and OECD stock markets: A multivariate approach. Economics Bulletin, 34(1), 510-519.

Gupta, R., \& Modise, M. P. (2013). Does the source of oil price shocks matter for South African stock returns? A structural VAR approach. Energy Economics, 40, 825-831.

Hammoudeh, S., Dibooglu, S., \& Aleisa, E. (2004). Relationships among us oil prices and oil industry equity indices. International Review of Economics 85 Finance, 13(4), 
$427-453$.

Hosseini Nasab, S., Khezri, M., \& Rasouli, A. (2011). Determining the impacts of oil price fluctuations on stock returns in Tehran stock exchange: Wavelet analysis and Markov switching. Energy Economics Review Quarterly, 8(29), 31-60.

Huang, R. D., Masulis, R. W., \& Stoll, H. R. (1996). Energy shocks and financial markets. The Journal of Futures Markets (1986-1998), 16(1), 1-27.

Jammazi, R., \& Nguyen, D. K. (2015). Responses of international stock markets to oil price surges: A regime-switching perspective. Applied Economics, 47(41), 4408-4422.

Jebran, K., Chen, S., Saeed, G., \& Zeb, A. (2017). Dynamics of oil price shocks and stock market behavior in Pakistan: Evidence from the 2007 financial crisis period. Financial Innovation, 3(1), 1-12.

Jones, C. M., \& Kaul, G. (1996). Oil and the stock markets. The Journal of Finance, $51(2), 463-491$.

Jorion, P. (1990). The exchange-rate exposure of US multinationals. Journal of Business, 331-345.

Kilian, L., \& Park, C. (2009). The impact of oil price shocks on the US stock market. International Economic Review, 50(4), 1267-1287.

Lee, Y.-H., \& Chiou, J.-S. (2011). Oil sensitivity and its asymmetric impact on the stock market. Energy, 36(1), 168-174.

Mohanty, S. K., Nandha, M., Turkistani, A. Q., \& Alaitani, M. Y. (2011). Oil price movements and stock market returns: Evidence from Gulf Cooperation Council (GCC) countries. Global Finance Journal, 22(1), 42-55.

Monjazeb, M., \& Gohari, H. H. (2013). Impact of oil exports income on Tehran stock exchange dividend and price index (TEDPIX) model selection. World Applied Sciences Journal, 22(6), 819-823.

Naurin, A., \& Qayyum, A. (2016). Impact of oil price and its volatility on CPI of Pakistan: Bivariate EGARCH Model. MPRA Available at: https://mpra.ub.unimuenchen.de/70636/.

Papapetrou, E. (2001). Oil price shocks, stock market, economic activity and employment in Greece. Energy Economics, 23(5), 511-532.

Park, J., \& Ratti, R. A. (2008). Oil price shocks and stock markets in the US and 13 European countries. Energy Economics, 30(5), 2587-2608.

Pesaran, M. H., Shin, Y., \& Smith, R. J. (2001). Bounds testing approaches to the analysis of level relationships. Journal of Applied Econometrics, 16(3), 289-326.

Ramos, S. B., \& Veiga, H. (2013). Oil price asymmetric effects: Answering the puzzle in international stock markets. Energy Economics, 38, 136-145.

Sadorsky, P. (1999). Oil price shocks and stock market activity. Energy Economics, 21(5), 449-469.

Sadorsky, P. (2000). The empirical relationship between energy futures prices and exchange rates. Energy Economics, 22(2), 253-266.

Shin, Y., Yu, B., \& Greenwood-Nimmo, M. (2014). Modelling asymmetric cointegration and dynamic multipliers in a nonlinear ARDL framework. In Festschrift in honor of peter schmidt (pp. 281-314). Springer. 
Wang, Y., Wu, C., \& Yang, L. (2013). Oil price shocks and stock market activities: Evidence from oil-importing and oil-exporting countries. Journal of Comparative Economics, 41(4), 1220-1239.

Yahyazadehfar, M., Shams, S., \& Garshasebi, A. (2012). Comparative analysis of stocks returns predictable factors in Tehran stocks exchange and New York stocks exchange using artificial neural network and linear regression. African Journal of Business Management, 6(2), 501-513. 